\title{
INFLUENCE OF COOLING METHODS ON THE MICROSTRUCTURE EVOLUTION OF THE CARBURIZED LAYER IN 18CNiMo7-6 STEEL AFTER HIGH-TEMPERATURE CARBURIZING
}

\author{
VPLIV NAČINA OHLAJEVANJA PO VISOKOTEMPERATURNI \\ CEMENTACIJI NA RAZVOJ MIKROSTRUKTURE CEMENTIRANE \\ PLASTI NA 18CrNiMo7-6 JEKLU
}

\author{
Xiao-xue An, Yong Tian*, Hao-jie Wang, Zhao-dong Wang \\ State Key Laboratory of Rolling and Automation, Northeastern University, No. 3-11 Wenhua Road, Heping District, Shenyang, China
}

Prejem rokopisa - received: 2019-12-19; sprejem za objavo - accepted for publication: 2020-03-29

doi:10.17222/mit.2019.298

The microstructure and mechanical properties of carburized gears vary significantly if treated with different cooling methods after high-temperature carburizing. In this study, the microstructure and hardness distribution of the carburized layer in the $18 \mathrm{CrNiMo7}-6$ steel after different quenching and cryogenic treatments were compared using a scanning electron microscope, Vickers hardness tester and X-ray diffractomer. The results indicate that both cooling methods, quenching and cryogenic treatment, had a significant influence on the amount of carbides and retained austenite in the carburized layer of the $18 \mathrm{CrNiMo7-6}$ steel. Fine carbides gradually dissolved with the increase in the quenching temperature. When the quenching temperature was higher than $850^{\circ} \mathrm{C}$, fine carbides were completely dissolved. The amount of the retained austenite decreased with the cryogenic temperature. When the cryogenic temperature was lower than $-120{ }^{\circ} \mathrm{C}$, there was no significant decrease in the amount of the retained austenite. In addition, after different quenching and cryogenic treatments, there was no remarkable change in the effective case depth of the carburized $18 \mathrm{CrNiMo} 7-6$ steel. Therefore, from the perspective of the dissolution of carbides and the amount of retained austenite, $850{ }^{\circ} \mathrm{C}$ and $-120^{\circ} \mathrm{C}$ were the optimum quenching and cryogenic temperatures of the $18 \mathrm{CrNiMo7}-6$ steel after high-temperature carburizing.

Keywords: 18CNiMo7-6 steel, quenching, cryogenic treatment, microstructure of the carburized layer

Mikrostrukture in mehanske lastnosti cementiranih mehanskih sklopov se lahko močno razlikujejo med seboj zaradi različnih pogojev ohlajevanja po visoko temperaturni cementaciji. V članku avtorji opisujejo študijo mikrostrukture in porazdelitve trdote po preseku cementirane plasti cementiranega jekla $18 \mathrm{CrNiMo7-6}$ po različnih načinih kaljenja in postopkih podhlajevanja. Nastale mikrostrukture so med seboj primerjali s pomočjo vrstičnega elektronskega mikroskopa in rentgenskega difraktometra. Trdoto nastalih plasti so merili z Vickersovim merilnikom mikrotrdote. Rezultati raziskav so pokazali, da imata tako metoda ohlajevanja kot podhlajevanja pomemben vpliv na vsebnost karbidov in zaostalega austenita $\mathrm{v}$ plasti cementiranega jekla 18CrNiMo7-6. Drobni karbidi se postopoma raztapljajo z naraščanjem temperature austenitizacije. Ko je le-ta višja od $850{ }^{\circ} \mathrm{C}$ se drobni karbidi popolnoma raztopijo v austenitni osnovi. Vsebnost zaostalega austenita se zmanjšuje z zniževanjem temperature podhlajevanja. Ko je temperatura podhlajevanja nižja od $-120{ }^{\circ} \mathrm{C}$ ni več pomembne spremembe $\mathrm{v}$ vsebnosti zaostalega austenita. Dodatno avtorji ugotavljajo, da pri različnih načinih kaljenja in različnih metodah podhlajevanja ne pride do bistvene spremembe debeline (globine) cementirane plasti cementiranega jekla 18CrNiMo7-6. Zato avtorji raziskave ocenjujejo da je, glede na raztapljanje karbidov in vsebnost zaostalega austenita, optimalna temperatura austenitizacije za visokotemperaturno cementacijo jekla $18 \mathrm{CrNiMo} 7-6$ enaka $850{ }^{\circ} \mathrm{C}$ in optimalna temperatura podhlajevanja enaka $-120{ }^{\circ} \mathrm{C}$.

Ključne besede: jeklo 18CrNiMo7-6, kaljenje, podhlajevanje, mikrostruktura cementirane plasti

\section{INTRODUCTION}

$18 \mathrm{CrNiMo7-6}$ steel is widely used because of its high strength, good toughness and wear resistance. Its applications are mainly found in the manufacture of wind-power, mine-reducer and high-speed locomotive gears, which need to be hardened with heat treatments after forging. ${ }^{1,2}$ Carburizing is one of the most commonly used techniques for improving the wear resistance of components such as gears and bearings. ${ }^{3-5}$ It enables the surfaces of the components made of low-carbon steel to achieve a high-carbon content. ${ }^{6-8}$ Therefore, carburizing

*Corresponding author's e-mail:

neu81@126.com (Yong Tian) is the key process in the manufacture of $18 \mathrm{CrNiMo7-6}$ gears. Besides, 18CrNiMo7-6 gears typically require deep carburization. Deep carburization usually takes tens of hours at the normal carburizing temperature of $930{ }^{\circ} \mathrm{C}$. Increasing the carburizing temperature could effectively shorten the process time. However, high-temperature carburizing (the carburizing temperature is higher than $930{ }^{\circ} \mathrm{C}$ ) tends to cause the austenite-grain coarsening of the steel, thereby deteriorating the properties of the components. ${ }^{9-11}$ In addition, the cooling process is an important part of industrial carburizing and it provides a way to control the mechanical properties of steel components. The temperature fields generated within the material under different cooling conditions result in different types of phase transition, grain size, 
Table 1: Chemical composition of the experimental steel (in mass fractions $(w / \%)$ )

\begin{tabular}{|c|c|c|c|c|c|c|c|c|c|c|}
\hline $\mathrm{C}$ & $\mathrm{Si}$ & $\mathrm{Mn}$ & $\mathrm{Cr}$ & $\mathrm{Ni}$ & $\mathrm{Mo}$ & $\mathrm{P}$ & $\mathrm{S}$ & $\mathrm{N}$ & $\mathrm{Nb}$ & $\mathrm{Ti}$ \\
\hline 0.19 & 0.22 & 0.56 & 1.48 & 1.63 & 0.32 & 0.0038 & 0.0034 & 0.0014 & 0.062 & 0.026 \\
\hline
\end{tabular}

residual deformation and hardness distribution. ${ }^{12}$ Therefore, the desired mechanical properties of carburized gears can be obtained by controlling the cooling methods after the carburizing.

While most previous investigations focused on the carburizing process of the 18CrNiMo7-6 steel, there have been few systematic studies designed to provide the necessary fundamental information for optimizing the influence of the cooling methods after high-temperature carburizing. ${ }^{13,14}$ The microstructure of the carburized layer in steel mainly consists of martensite, carbides and retained austenite. The quenching process after hightemperature carburizing has a significant influence on the microstructure of the carburized layer in steel. Besides, by controlling the content of retained austenite, cryogenic treatment can effectively improve the hardness and wear resistance of many metallic materials. ${ }^{15-18}$ The cooling method needs to vary significantly due to the differences in the chemical composition of the materials, otherwise it may not be sufficient for creating the desired properties. ${ }^{19}$ Therefore, the cooling methods after hightemperature carburizing have a significant influence on the microstructure evolution of the carburized layer in the $18 \mathrm{CrNiMo7}-6$ steel. To predict and optimize the influence of cooling methods on the $18 \mathrm{CNiMo} 7-6$ steel after high-temperature carburizing with respect to the required material and technology, the present work was undertaken to experimentally investigate the microstructure evolution of the carburized layer during the quenching and cryogenic process.

\section{EXPERIMENTAL PART}

The test material in this research was $\mathrm{Nb}$ - $\mathrm{Ti}$ microalloyed 18CrNiMo7-6 steel. It was designed for hightemperature carburizing based on the results of a thermodynamic calculation. $\mathrm{Nb}$ and $\mathrm{Ti}$ additions were mainly designed for precipitating as the pinning particles. An ingot with a diameter of $150 \mathrm{~mm}$ and a height of $550 \mathrm{~mm}$ was produced in a vacuum-induction furnace. Subsequently, the ingot was reheated to $1200{ }^{\circ} \mathrm{C}$, held for $2 \mathrm{~h}$ and then forged into bars of $60 \mathrm{~mm}$ and $30 \mathrm{~mm}$ in diameter. The forged bars with the diameter of $30 \mathrm{~mm}$ were first held at $900{ }^{\circ} \mathrm{C}$ for $0.5 \mathrm{~h}$, then water quenched and tempered at $650{ }^{\circ} \mathrm{C}$ for $2 \mathrm{~h}$. The chemical composition of the experimental steel detected with a direct-reading spectrometer is shown in Table $\mathbf{1}$.

Figure 1 shows the thermal cycles of the carburizing, quenching and cryogenic treatments. The specimens for carburizing were machined to dimensions of $(20 \times 10 \times 6)$ $\mathrm{mm}$. The carburizing process was performed in a vacuum furnace. In order to achieve the desired thickness of the carburized layer, the $\mathrm{C}_{2} \mathrm{H}_{2}$ and $\mathrm{N}_{2}$ gas were alternately injected into the vacuum furnace during the carburizing and diffusion processes. The carburizing temperature was $1050{ }^{\circ} \mathrm{C}$. After that, the specimens were quenched in an oil box.

Carburized specimens were reheated to $(790,820$, 850 and 880$){ }^{\circ} \mathrm{C}$. Afterwards, they were held for $0.5 \mathrm{~h}$ at the selected temperature and cooled to room temperature with a cooling rate of $20{ }^{\circ} \mathrm{C}$ per second. A high-temperature laser-scanning confocal microscopy was used for simulating the quenching process and observing the microstructure evolution of the specimens.

The cryogenic treatments were performed in a DY-W/0.08-C cryogenic container. The carburized specimens were held at $(-50,-120$ and -190$){ }^{\circ} \mathrm{C}$ for $2 \mathrm{~h}$. Finally, they were slowly warmed up to room temperature in air.

The phase-transformation behaviour of the 18CrNiMo7-6 steel during heating and cooling was investigated using a Formastor-FII phase-transformation testing instrument. And the critical phase-transformation

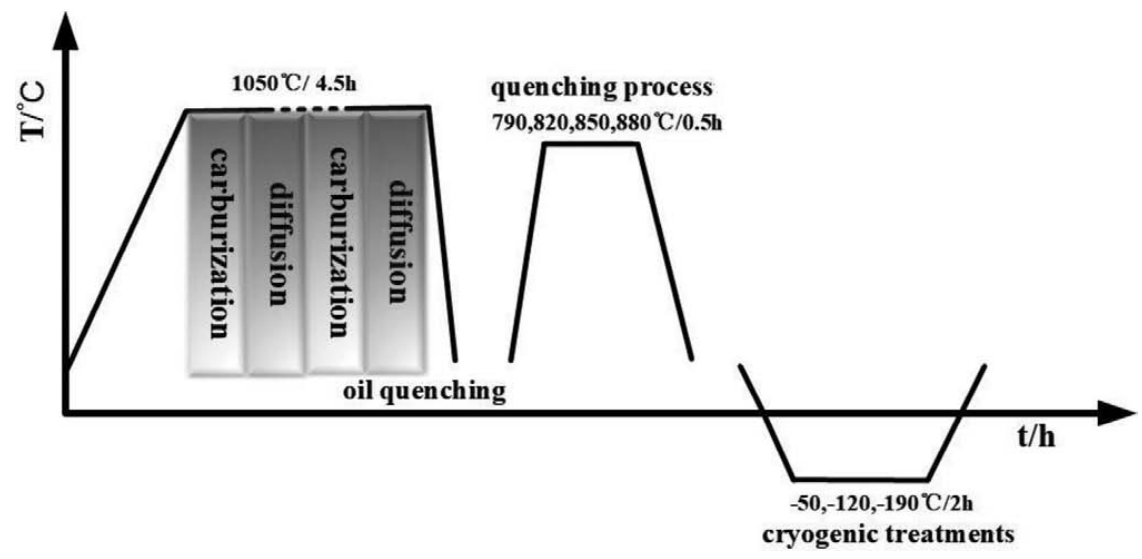

Figure 1: Thermal cycles of the carburizing, quenching and cryogenic treatments 
point temperatures of the $18 \mathrm{CrNiMo} 7-6$ steel were 654 and $785^{\circ} \mathrm{C}$.

Metallographic specimens were mechanically ground and polished according to the standard metallographic procedure. They were then chemically etched in $4-\%$ nital. Optical microscopy (OM), scanning electron microscopy (SEM) and energy-dispersive X-ray spectroscopy (EDS) were used to characterize the microstructure and identify the chemical composition of carbides. X-ray diffraction technique was also used for the determination of retained austenite. Hardness tests were carried out on a Vickers micro-hardness tester. The Vickers indentation load was 300 gf. Besides, at least three indentation-hardness tests were made and the average value was taken.

\section{RESULTS AND DISCUSSION}

\subsection{Microstructure and hardness of the carburized layer after high-temperature carburizing}

Figure 2 shows the microstructures of the carburized layer and core in the 18CrNiMo7-6 steel directly quenched after high-temperature carburizing at $1050{ }^{\circ} \mathrm{C}$. As shown in Figure 2a, the needle-type martensite distributed within the prior austenite grains was observed in
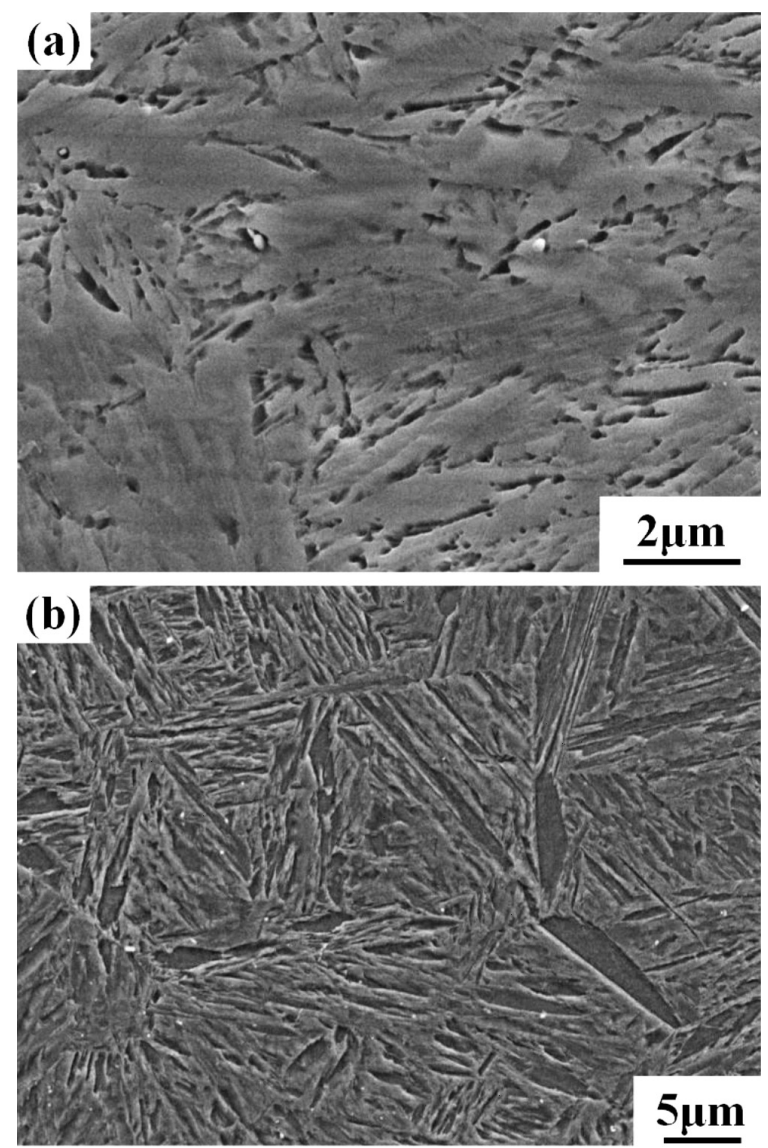

Figure 2: Microstructures of the: a) carburized layer and b) core of the $18 \mathrm{CrNiMo} 7-6$ steel directly quenched after high-temperature carburizing at $1050{ }^{\circ} \mathrm{C}$ the carburized layer of the $18 \mathrm{CrNiMo7}-6$ steel. And it is evident that the carburized 18CrNiMo7-6 steel had lath martensite in the core, as shown in Figure $\mathbf{2 b}$. On the other hand, there were some precipitates distributed in the martensite structures. Due to the presence of $\mathrm{Nb}$ and $\mathrm{Ti}$, it is easy for the steel to produce precipitates such as $\mathrm{NbC}, \mathrm{Ti}(\mathrm{C}, \mathrm{N})$ and $(\mathrm{Nb}, \mathrm{Ti}) \mathrm{C}$. Some of these precipitates have excellent high-temperature stability so they remained undissolved at $1050{ }^{\circ} \mathrm{C}$. Therefore, precipitates of $\mathrm{NbC}, \mathrm{Ti}(\mathrm{C}, \mathrm{N})$ or $(\mathrm{Nb}, \mathrm{Ti}) \mathrm{C}$ were observed in the 18CrNiMo7-6 steel directly quenched after high-temperature carburizing at $1050{ }^{\circ} \mathrm{C}$.

Figure 3 shows the hardness distribution of the 18CrNiMo7-6 steel directly quenched after high-temperature carburizing at $1050{ }^{\circ} \mathrm{C}$. The surface hardness of the carburized 18CrNiMo7-6 steel was 746 HV0.3. Figure 3 reveals that the hardness of the surface was lower than that of the subsurface. This resulted from the presence of retained austenite. Compared with the subsurface of the steel, the higher carbon concentration of the surface increased the stability of austenite, resulting in a larger amount of retained austenite on the surface. And the surface hardness was reduced by the "softening" behaviour of the retained austenite. As the carbon concentration decreased with the distance from the surface, the amount of the retained austenite also decreased. The "softening" effect of retained austenite cannot offset the "hardening" effect of a high carbon concentration. The hardness of the near-surface region increased. After reaching the equilibrium point, the "softening" effect of retained austenite no longer played the leading role and the hardness of the carburized layer decreased with the carbon concentration.

\subsection{Microstructure and hardness of the carburized layer after different quenching treatments}

Figure 4 shows the microstructure of the carburized layer in 18CrNiMo7-6 steels that were quenched at (790,

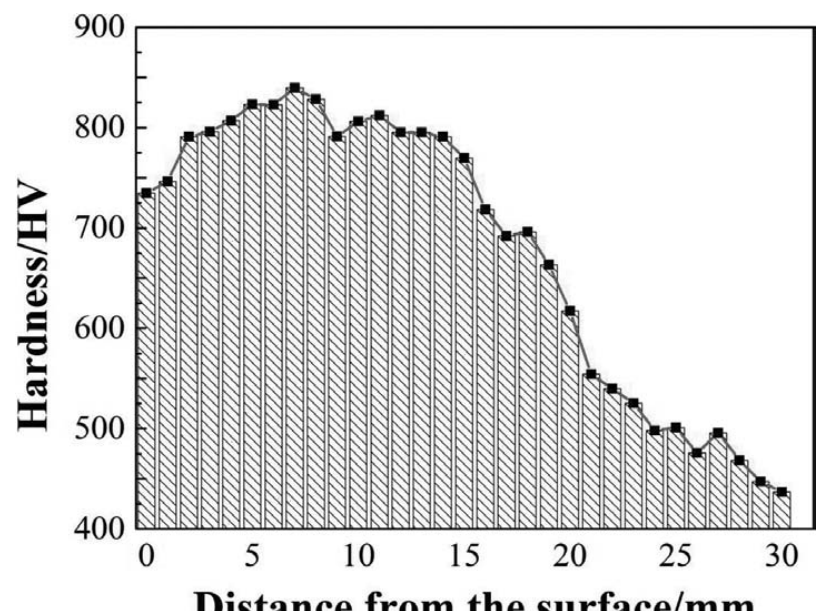

Figure 3: Hardness distribution of the 18CrNiMo7-6 steel directly quenched after high-temperature carburizing at $1050{ }^{\circ} \mathrm{C}$ 
820, 850 and 880) ${ }^{\circ} \mathrm{C}$, respectively. Compared with Figure 2, Figure 4a shows that a large amount of fine carbides were uniformly distributed in the matrix with some undissolved large-sized carbides. This may be attributed to the high carbon concentration of the carburized layer during the high-temperature carburizing process. The carbon concentration of the steel directly quenched after high-temperature carburizing at $1050{ }^{\circ} \mathrm{C}$ exceeded the saturated carbon concentration of the steel quenched at a relatively low temperature of $790{ }^{\circ} \mathrm{C}$. And a large amount of carbides precipitated. As shown in Figure $\mathbf{4 b}$, most of the fine carbides were dissolved but some were still observable. In Figures $\mathbf{4 c}$ and $\mathbf{4 d}$, the fine carbides were completely dissolved except for some large-sized carbides. This indicates that the quenching treatments had a significant effect on the amount of carbides in the carburized layer. The carbides gradually dissolved with the increase of the quenching temperature. When the quenching temperature was higher than $850{ }^{\circ} \mathrm{C}$, the fine carbides were completely dissolved.

In order to determine the types and changes of these carbides after different quenching treatments, thermoCalc simulations and an EDS analysis were performed on the carburized layer. As the surface carbon concentration was controlled at $0.8 \%$ during the carburizing process, the fundamental equilibrium thermodynamic analysis was based on the assumption that the carbon concentration of the carburized layer was $0.8 \%$. Figure 5 shows simulation results for the carburized layer. Figure 6 shows SEM micrographs and EDS analysis of the carburized layers in the $18 \mathrm{CrNiMo} 7-6$ steels, quenched at $(1050,790$ and 820$){ }^{\circ} \mathrm{C}$. It indicates that the large-sized carbides in the carburized layer of the $18 \mathrm{CrNiMo7}-6$ steel directly quenched at $1050{ }^{\circ} \mathrm{C}$ were $\mathrm{Nb} / \mathrm{Ti}$-containing carbides. The large-sized carbides in the carburized layers of the steels quenched at 790 and $820{ }^{\circ} \mathrm{C}$ were $\mathrm{Cr}$-containing carbides and $\mathrm{Nb}$ /Ti-containing carbides, respectively. With the increase in the quenching temperature, there were only large-sized $\mathrm{Nb}$ /Ti-containing carbides in the carburized layers of the $18 \mathrm{CrNiMo7}-6$ steels quenched at $820{ }^{\circ} \mathrm{C}$ and $1050{ }^{\circ} \mathrm{C}$. These results were consistent with Figure 5.

As shown in Figure 5, the amount of cementite and Cr-containing carbides decreased with the temperature. At the temperature of $790{ }^{\circ} \mathrm{C}$, there were a large amount of cementite and some $\mathrm{M}_{23} \mathrm{C}_{6}$ in the carburized layer of the $18 \mathrm{CrNiMo} 7-6$ steel. There were a certain amount of
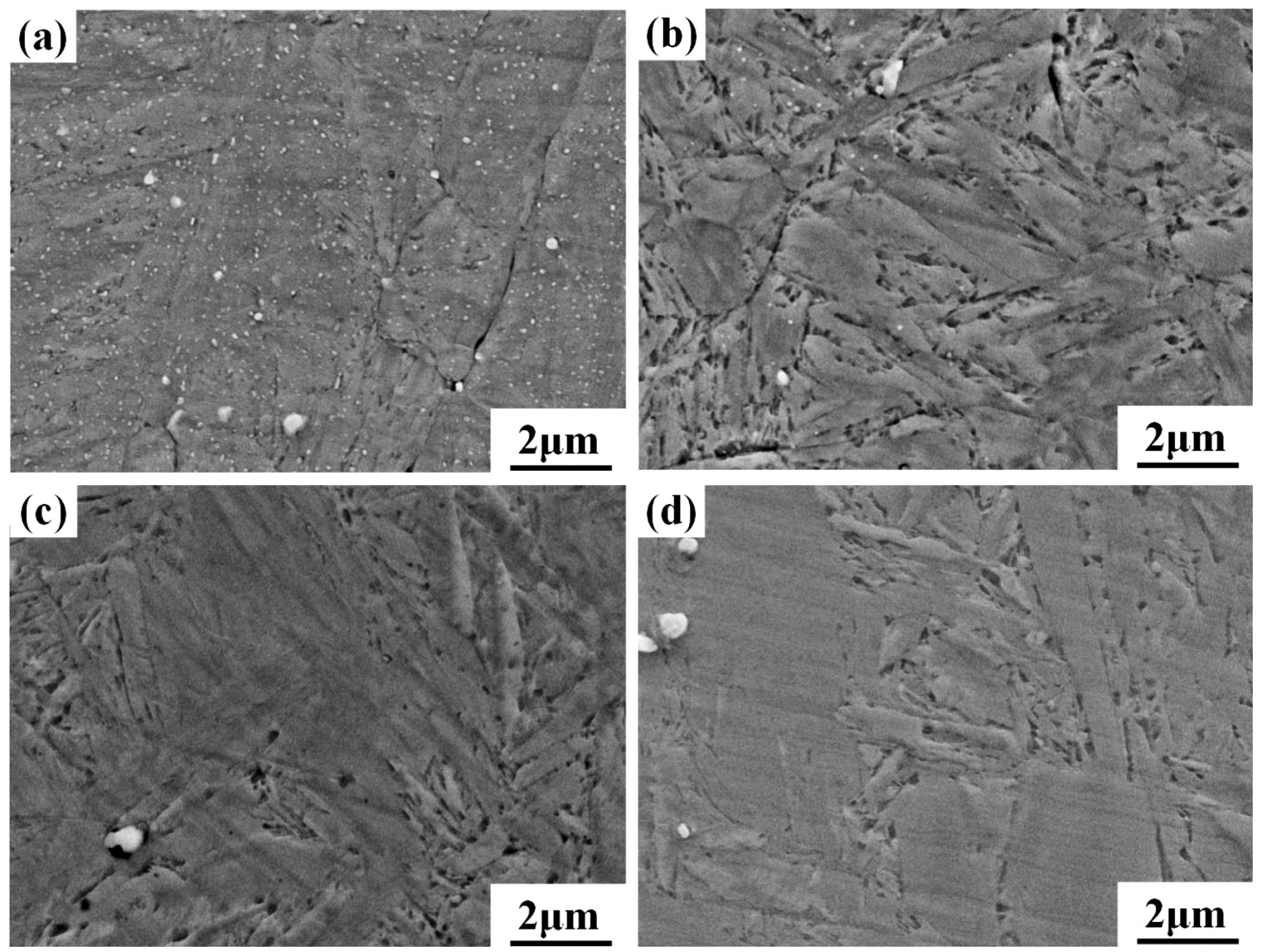

Figure 4: Microstructures of the carburized layers in the $18 \mathrm{CrNiMo} 7-6$ steels quenched at: a) $790{ }^{\circ} \mathrm{C}$, b) $820{ }^{\circ} \mathrm{C}$, c) $850{ }^{\circ} \mathrm{C}$ and d) $880{ }^{\circ} \mathrm{C}$ 


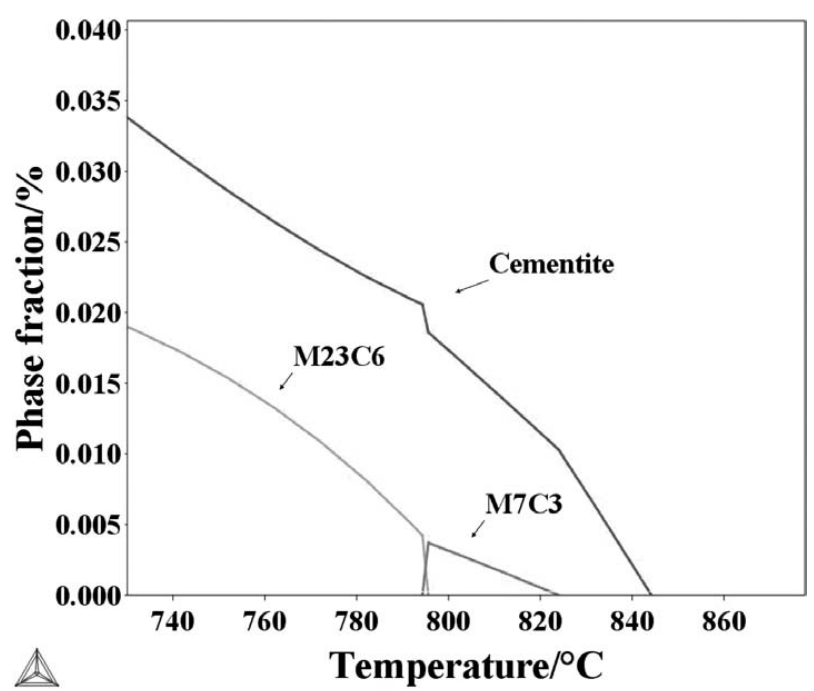

Figure 5: Thermo-Calc simulations of cementite, $\mathrm{M}_{23} \mathrm{C}_{6}$ and $\mathrm{M}_{7} \mathrm{C}_{3}$ phase fractions in the carburized layer of the $18 \mathrm{CrNiMo7}-6$ steel

cementite and little $\mathrm{M}_{7} \mathrm{C}_{3}$ in the carburized layer at the temperature of $820{ }^{\circ} \mathrm{C}$. But the total amount of carbides was significantly reduced. Once the temperature was higher than $850{ }^{\circ} \mathrm{C}$, there were no cementite or $\mathrm{Cr}$-containing carbides in the carburized layer of the $18 \mathrm{CrNiMo7}-6$ steel. The change in the total amount of fine carbides from Figure $\mathbf{4}$ is basically consistent with the simulation results from Figure 5. Therefore, the thermodynamic simulation of the carburized layer can be successfully employed to predict the microstructure evolution for the carburized $18 \mathrm{CrNiMo} 7-6$ steel in the quenching process.

In addition, this indicates that the fine carbides in the carburized layer of the $18 \mathrm{CrNiMo} 7-6$ steels were cementite, $\mathrm{M}_{23} \mathrm{C}_{6}$ and $\mathrm{M}_{7} \mathrm{C}_{3}$. And the undissolved largesized carbides during the quenching process were $\mathrm{Nb}$ /Ti-containing carbides. This was attributed to the high thermal stability of $\mathrm{Nb}-\mathrm{Ti}$ precipitates. The microalloying elements such as niobium and titanium in the 18CrNiMo7-6 steel have a tendency to precipitate as carbides. The high carbon concentration of the carburized layer facilitated the formation of $\mathrm{Nb} / \mathrm{Ti}$-containing carbides and, consequently, increased its stability. The increasing temperature increases the solubility and coarsening rate of the carbides. After exceeding the critical size, the $\mathrm{Nb} / \mathrm{Ti}$-containing carbides do not dissolve due to the growth and coarsening at elevated temperatures. ${ }^{14}$ The corresponding quenching temperature should be selected to avoid further coarsening and growth of the $\mathrm{Nb} / \mathrm{Ti}$-containing carbides.

While the quenching temperature is relatively high, carburized gears are prone to generate severe deformation and quenching cracks. On the other hand, the carbon concentration of the carburized layer is higher than the saturated carbon concentration of the steel at a very low quenching temperature. Then, a large amount of carbides precipitate inside the grains and at the grain boundaries. These carbides may grow and coarsen during the subsequent heat treatments, leading to the formation of some large-sized carbides, and sometimes even carbide networks. Therefore, a large amount of carbides should be avoided during a quenching process. From the perspective of the dissolution of carbides, the optimum quenching temperature for the carburized $18 \mathrm{CrNiMo7}-6$ steel was $850{ }^{\circ} \mathrm{C}$.

Figure 7 shows the hardness distribution of the carburized layers in the $18 \mathrm{CrNiMo} 7-6$ steels that were quenched at $(790,820,850$ and 880$){ }^{\circ} \mathrm{C}$. The effective case depth was defined as the perpendicular distance from the surface to the place where the hardness was equal to $550 \mathrm{HV}$. Compared with Figure 3, Figures 7a to $\mathbf{7 d}$ indicate that the amount of retained austenite on the surface was significantly reduced. Compared with the quenching temperatures higher than $820{ }^{\circ} \mathrm{C}$, the diffu-
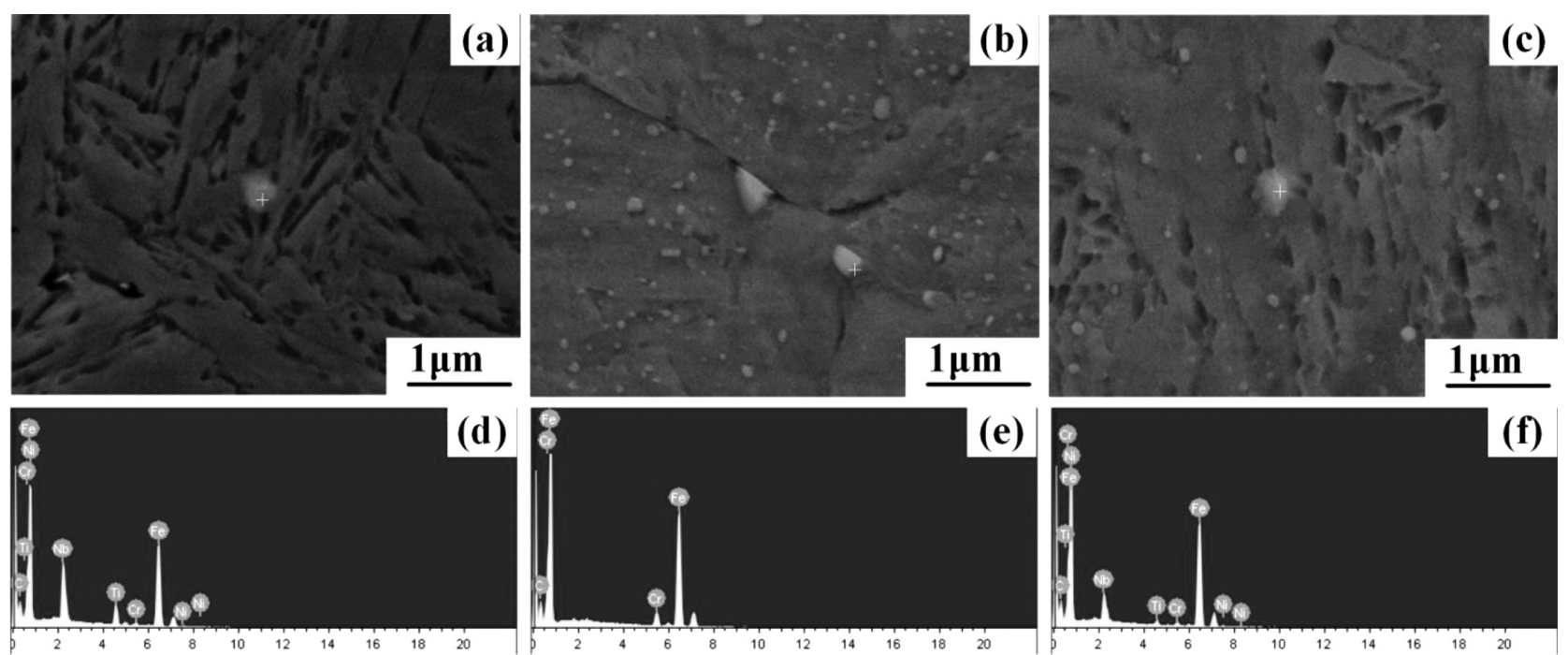

Figure 6: SEM micrographs and an EDS analysis of the carburized layers in the $18 \mathrm{CrNiMo} 7-6$ steels quenched at: a), d) $1050{ }^{\circ} \mathrm{C}$; b), e) $790{ }^{\circ} \mathrm{C}$ and c), f) $820^{\circ} \mathrm{C}$, respectively 

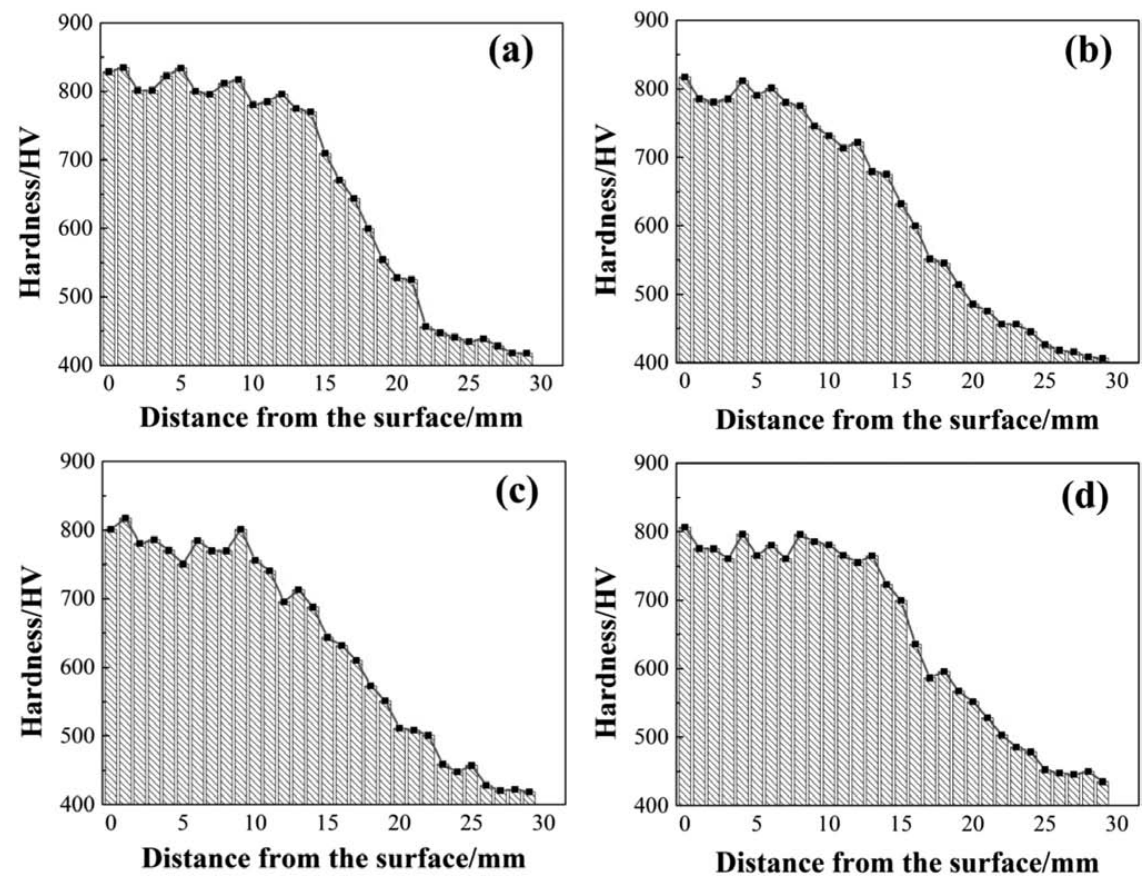

Figure 7: Hardness distribution of the carburized layers in the $18 \mathrm{CrNiMo} 7-6$ steels quenched at: a) $790{ }^{\circ} \mathrm{C}$, b) $820{ }^{\circ} \mathrm{C}$, c) $850{ }^{\circ} \mathrm{C}$ and d) $880{ }^{\circ} \mathrm{C}$, respectively

sion rate of carbon atoms was lower at the quenching temperature of $790{ }^{\circ} \mathrm{C}$. Thus, the steel quenched at $790{ }^{\circ} \mathrm{C}$ had the highest surface hardness of $828 \mathrm{HV} 0.3$. On the other hand, the surface hardness of the steels quenched at $(820,850$ and 880$){ }^{\circ} \mathrm{C}$ were $817 \mathrm{HV} 0.3,801$ HV0.3 and 806 HV0.3, respectively.

The hardness of the subsurface of the steel quenched at $820{ }^{\circ} \mathrm{C}$ was the lowest. This was caused by the combination of the carbon-diffusion behaviour and cooling conditions, which resulted in more retained austenite in the subsurface than on the surface. At the quenching temperature of $850{ }^{\circ} \mathrm{C}$, the carbon atoms diffused evenly. And the hardness gradually decreased due to a gradual decrease in the carbon concentration from the surface to the core. Compared with the quenching temperatures below $850{ }^{\circ} \mathrm{C}$, the hardness gradually decreased because the "softening" effect of retained austenite on the surface and near the surface area no longer played the leading role. At the quenching temperature of $880{ }^{\circ} \mathrm{C}$, the diffusion coefficient of carbon atoms was relatively high.
Within a certain distance, the hardness of the nearsurface region did not change much. On the other hand, the effective case depths of the steels quenched at $790{ }^{\circ} \mathrm{C}$ to $880^{\circ} \mathrm{C}$ were similar. This indicates that the quenching treatments had little effect on the effective case depth of the carburized 18CrNiMo7-6 steel.

\subsection{Microstructure and hardness of the carburized layer after different cryogenic treatments}

Figure 8 shows the microstructures of the carburized layers in the $18 \mathrm{CrNiMo7}-6$ steels that were cryogenically treated at $(-50,-120$ and -190$){ }^{\circ} \mathrm{C}$, respectively. The amount and distribution of the carbides in the steels after different cryogenic treatments had no significant difference. Under normal circumstances, the volume of martensite shrank and the lattice constant of Fe became smaller after the cryogenic treatments. This also promoted the precipitation of carbon atoms. The quenched martensite was in a thermodynamically unstable state,
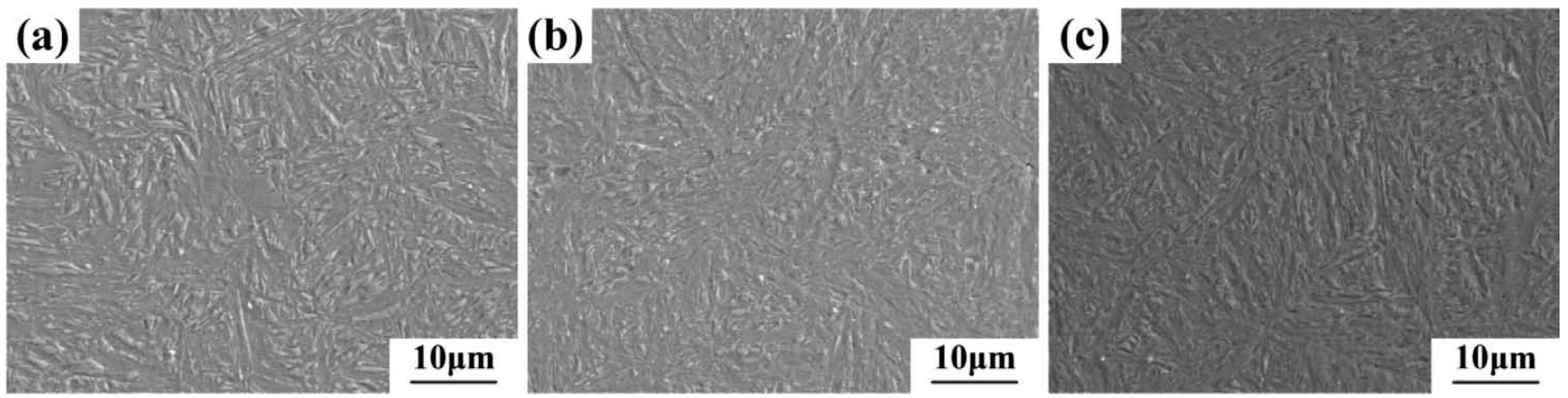

Figure 8: Microstructures of the carburized layers in the $18 \mathrm{CrNiMo} 7-6$ steels cryogenically treated at: a) $-50{ }^{\circ} \mathrm{C}$, b) $-120{ }^{\circ} \mathrm{C}$ and c) $-190{ }^{\circ} \mathrm{C}$ 
and the decomposition driving force was large. However, the precipitation and coarsening of the carbides at a low temperature were difficult. Since the steels were not tempered after the cryogenic treatments, it is possible that some very fine carbides precipitated on the martensite matrix. But the carbides of the steel without the tempering treatment were so small that no significant changes were observed with scanning electron microscopy.

Figure 9 shows the hardness distribution and XRD patterns of the $18 \mathrm{CrNiMo7}-6$ steels after different cryogenic treatments. The surface hardness of the steels cryogenically treated at $(-50,-120$ and -190$){ }^{\circ} \mathrm{C}$ were 858 HV0.3, 845 HV0.3 and 834 HV0.3, respectively. Compared with Figure 3, there was a remarkable increase in the surface hardness of all the steels after the cryogenic treatment. The reason was that the amount of the retained austenite on the surface was significantly reduced as shown in Figure 9d. According to the calculation results of the XRD patterns, the amount of the retained austenite on the surface of the steel directly quenched at $1050{ }^{\circ} \mathrm{C}$ was $22 \%$. The carburized layer of the $18 \mathrm{CrNiMo} 7-6$ steel contained a large amount of carbon and alloying elements such as chromium, nickel and molybdenum. It enhanced the stability of austenite and significantly decreased the transformation-point temperature of martensite. As a result, there was a large amount of retained austenite in the carburized layers of the steels after the quenching. And the retained austenite in the steel decomposed and transformed into martensite at lower temperatures, improving the hardness and wear resistance of the steel.

Based on calculations, the amounts of retained austenite on the surfaces of the steels cryogenically treated at $(-50,-120$ and -190$){ }^{\circ} \mathrm{C}$ were $(17,10$ and 12$) \%$, respectively. This indicates that the cryogenic treatment at $-50{ }^{\circ} \mathrm{C}$ could promote the transformation of retained austenite to martensite and increase the hardness of the surface. The amount of the retained austenite decreased with the decrease in the cryogenic temperature. However, when the cryogenic temperature was lower than $-120{ }^{\circ} \mathrm{C}$, there was no remarkable change in the amount of the retained austenite. Another point needs to be mentioned: the surface hardness of the steels cryogenically treated at different temperatures did not increase with the decrease in the amount of retained austenite. On the contrary, the surface hardness decreased with the decrease in the cryogenic temperature. This suggests that some other phenomena took place inside the steel (or in its carburized layer) during the cryogenic treatment, leading to the hardness change. This supports the hypothesis of a fine-carbide precipitation during the cryogenic treatment. From this point of view, the hardness enhancement was a competition between the precipitation strengthening of the carbides and the "softening" effect of the retained austenite. On the other hand, the effective case depths of the steels cryogenically treated at $(-50,-120$ and -190$){ }^{\circ} \mathrm{C}$ were similar. This indicates that the cryogenic treatments had little effect on the effective case depth of the carburized 18CrNiMo7-6 steel.
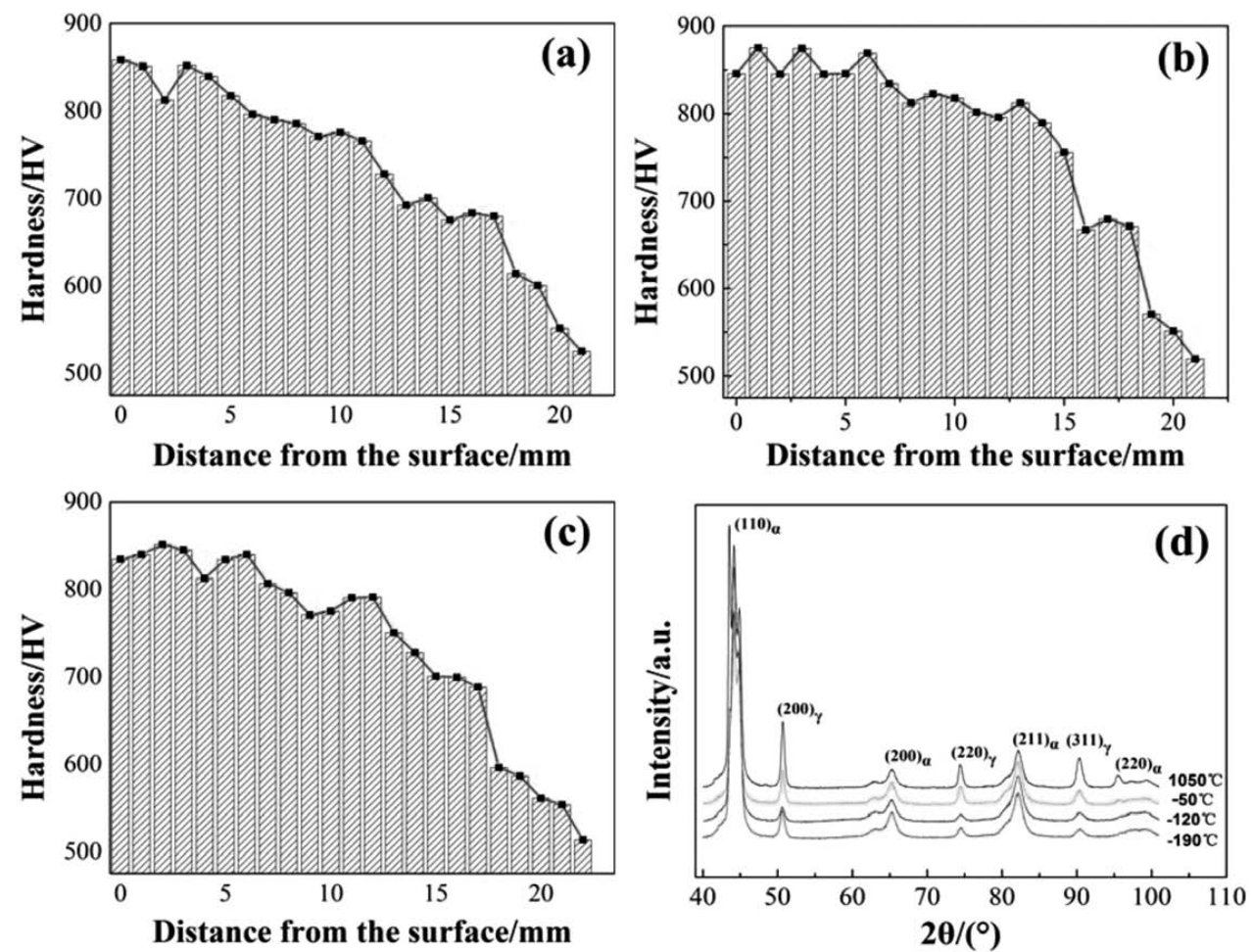

Figure 9: Hardness distribution of the carburized layers in the $18 \mathrm{CrNiMo} 7-6$ steels cryogenically treated at: a) $\left.-50{ }^{\circ} \mathrm{C}, \mathrm{b}\right)-120{ }^{\circ} \mathrm{C}$, c) $-190{ }^{\circ} \mathrm{C}$, and d) XRD patterns of the surfaces after different cryogenic treatments 


\section{CONCLUSIONS}

Most of the fine carbides in the carburized layer of the $18 \mathrm{CrNiMo} 7-6$ steel after quenching were cementite and Cr-containing carbides. They gradually dissolved with the quenching temperature. When the quenching temperatures were higher than $850{ }^{\circ} \mathrm{C}$, the fine carbides were completely dissolved.

After high-temperature carburizing, the surface hardness of the $18 \mathrm{CrNiMo7}-6$ steel was lower than that of the subsurface due to the "softening" effect of retained austenite in the carburized layer. The cryogenic treatment promoted the transformation of retained austenite and increased the hardness of the surface. The amount of the retained austenite decreased with the cryogenic temperature. When the cryogenic temperature was lower than $-120{ }^{\circ} \mathrm{C}$, there was no significant decrease in the amount of retained austenite.

Both cooling methods, quenching and cryogenic treatment, had a significant influence on the amount of carbides and retained austenite in the carburized layer of the $18 \mathrm{CrNiMo} 7-6$ steel. From the perspective of the dissolution of carbides and the amount of retained austenite, the optimum quenching temperature and cryogenic temperature of the $18 \mathrm{CrNiMo} 7-6$ steel after hightemperature carburizing were $850{ }^{\circ} \mathrm{C}$ and $-120{ }^{\circ} \mathrm{C}$.

\section{Acknowledgment}

The authors acknowledge the supports of the National Key Research and Development Program of China (2017YFB0305300), the Fundamental Research Funds for the Central Universities (N170712017) and the Fundamental Research Funds for the Central Universities (N160708001).

\section{REFERENCES}

${ }^{1}$ P. Springer, U. Prahl, Pinning effect of strain induced $\mathrm{Nb}(\mathrm{C}, \mathrm{N})$ on layer hardening steel under warm forging conditions, J. Mater. Process. Technol., 253 (2018), 121-133, doi:10.1016/j.jmatprotec. 2017.11.008

${ }^{2}$ X. X. An, Y. Tian, H. J. Wang, Y. F. Shen, Z. D. Wang, Suppression of austenite grain coarsening by using $\mathrm{Nb}-\mathrm{Ti}$ microalloying in high temperature carburizing of a gear steel, Adv. Eng. Mater., 21 (2019) 8, 1-10, doi:10.1002/adem.201900132

${ }^{3}$ S. C. Cha, S. H. Hong, M. Y. Kim, J. Park, J. H. Shim, W. S. Jung, M. Rath, E. Kozeschnik, CALPHAD-based alloy design for advanced automotive steels - Part II: Compositional and microstructural modification for advanced carburizing steels, CALPHAD, 54 (2016), 172-180, doi:10.1016/j.calphad.2016.04.008

${ }^{4} \mathrm{H}$. Mohrbacher, Metallurgical concepts for optimized processing and properties of carburizing steel, Adv. Manuf., 4 (2016), 105-114, doi:10.1007/s40436-016-0142-9
${ }^{5}$ Z. K. Qiu, P. Z. Zhang, D. B. Wei, X. F. Wei, X. H. Chen, A study on tribological behavior of double-glow plasma surface alloying W-Mo coating on gear steel, Surf. Coat. Tech., 278 (2015), 92-98, doi:10.1016/j.surfcoat.2015.08.003

${ }^{6}$ O. Asi, A. Ç. Can, J. Pineault, M. Belassel, The effect of high temperature gas carburizing on bending fatigue strength of SAE 8620 steel, Mater. Des., 30 (2009), 1792-1797, doi:10.1016/j.matdes. 2008.07.020

${ }^{7}$ Y. Tian, H. J. Wang, X. X. An, Z. D. Wang, Experimental study on carbon flux in vacuum carburizing, Mater. Res. Express., 6 (2019) 9 , 1-10, doi:10.1088/2053-1591/ab2c4b

${ }^{8}$ N. M. Ryzhov, R. S. Fakhurtdinov, A. E. Smirnov, L. P. Fomina, Analysis of methods of carburizing of gears from heat-resistant steels, Met. Sci. Heat. Treat., 52 (2010) 5, 260-265, doi:10.1007/ s11041-010-9261-2

${ }^{9}$ Z. J. Xu, S. P. Wei, P. Zhou, J. C. Lu, G. Wang, Optimization of heat treatment process after vacuum carburizing of $18 \mathrm{Cr} 2 \mathrm{Ni} 4 \mathrm{WA}$ steel, Heat Treat. Met., 39 (2014) 9, 32-35, doi:10.13251/j.issn.02546051.2014.09.008

${ }^{10}$ J. W. Zhang, W. Li, H. Q. Wang, Q. P. Song, L. T. Lu, W. J. Wang, Z. G. Liu, A comparison of the effects of traditional shot peening and micro-shot peening on the scuffing resistance of carburized and quenched gear steel, Wear, 368 (2016), 253-257, doi:10.1016/ j.wear.2016.09.029

${ }^{11}$ Z. Y. Liu, Y. P. Bao, M. Wang, X. Li, F. Z. Zeng, Austenite grain growth of medium-carbon alloy steel with aluminum additions during heating process, Int. J. Min. Met. Mater., 26 (2019) 3, 282-290, doi:10.1007/s12613-019-1736-6

${ }^{12}$ P. R. Woodard, S. Chandrasekar, H. T. Y. Yang, Analysis of Temperature and Microstructure in the Quenching of Steel Cylinders, Metall. Mater. Trans. B, 30 (1999), 815-822, doi:10.1007/ s11663-999-0043-4

${ }^{13}$ Y. H. Yang, M. Q. Wang, J. C. Chen, H. Dong, Microstructure and Mechanical Properties of Gear Steels after High Temperature Carburization, J. Iron Steel Res. Int., 20 (2013) 12, 140-145, doi:10.1016/S1006-706X(13)60227-7

${ }^{14}$ T. Murakami, H. Hatano, Y. Shindo, M. Nagahama, H. Yaguchi, The Effects of $\mathrm{Nb}$ Carbo-nitride Precipitation Conditions on Abnormal Grain Growth in Nb Added Steels, Mater. Sci. Forum, 539 (2007), 4167-4172, doi:10.4028/www.scientific.net/MSF.539-543.4167

${ }^{15}$ H. Z. Li, W. P. Tong, J. J. Cui, H. Zhang, L. Q. Chen, L. Zuo, The influence of deep cryogenic treatment on the properties of high vanadium alloy steel, Mater. Sci. Eng. A, 662 (2016), 356-362, doi:10.1016/j.msea.2016.03.039

${ }^{16}$ R. Thornton, T. Slatter, H. Ghadbeigi, Effects of deep cryogenic treatment on the dry sliding wear performance of ferrous alloys, Wear, 305 (2013) 1-2, 177-191, doi:10.1016/j.wear.2013.06.005

${ }^{17}$ B. Podgornik, F. Majdic, V. Leskovsek, J. Vizintin, Improving tribological properties of tool steels through combination of deep-cryogenic treatment and plasma nitriding, Wear, 288 (2012), 88-93, doi:10.1016/j.wear.2011.04.001

${ }^{18} \mathrm{P}$. Baldissera, Fatigue scatter reduction through deep cryogenic treatment on the $18 \mathrm{NiCrMo5}$ carburized steel, Mater. Des., 30 (2009), 3636-3642, doi:10.1016/j.matdes.2009.02.019

${ }^{19}$ A. Sugianto, M. Narazaki, M. Kogawara, A. Shirayori, S. Y. Kim, S. Kubota, Numerical simulation and experimental verification of carburizing-quenching process of $\mathrm{SCr} 420 \mathrm{H}$ steel helical gear, J. Mater. Process. Technol., 209 (2009) 7, 3597-3609, doi:10.1016/ j.jmatprotec.2008.08.017 